\title{
Pengaruh Keadilan Organisasional terhadap Employee Engagement Dimoderasi Etika Kerja Islam
}

\author{
Novia Hariani, Muafi ${ }^{\bowtie}$ \\ Universitas Islam Indonesia \\ e-mail:muafi@uii.ac.id
}

\begin{abstract}
Justice is an important factor in improving employee performance. In its application, companies must apply good business ethics so that the relationship between justice and performance can increase. Several previous studies have discussed the relationship between fairness and performance, but still few have linked it to business ethics, especially Islamic business ethics. This study aims to determine This study aims to determine the effect of organizational justice on employee engagement moderated by Islamic work ethics at Ratu Samban University (UNRAS), Bengkulu. The sampling technique used in this study is the census method, which is taking the entire population as a sample of the study. Based on the number of population then the sample in this study amounted to 80 respondents. The research variables consist of independent variables namely distributive justice, procedural justice and interactional justice, the dependent variable is the Employee Engagement, and the moderation variable is the work ethic of Islam. Data analysis in this study using hirearki regression analysis. The results of this study prove that Distributive Justice has a significant positive effect on Employee Engagement, Procedural Justice has a significant positive effect on Employee Engagement, Interactional Justice has a significant positive effect on Employee Engagement, Islamic Work Ethics moderate the effect of Distributive Justice on Employee Engagement, Islamic Work Ethics moderate the effect of Procedural Justice on Employee Engagement and Islamic Work Ethics moderate the influence of Interactional Justice on Employee Engagement.
\end{abstract}

Keywords: Distributive justice, procedural justice, interactional justice, employee engagement and islamic work ethics

\begin{abstract}
Abstrak
Keadilan merupakan faktor penting dalammeningkatkankinerjakaryawan. Dalam penerapannya, perusahaan harus menerapkan etika bisnis yang baik sehingga hubungan keadilan dan kinerja semakin meningkat. Beberapa penelitian terdahulu banyak membahas hubungan antara keadilan dan kinerja, akan tetapi masih sedikit yang mengkaitkan dengan etika bisnis, khususnya etika bisnis Islam. Penelitian ini bertujuan untuk mengetahui pengaruh keadilan organisasi terhadap employee engagement yang dimoderasi oleh etika kerja Islam di Universitas Ratu Samban
\end{abstract}


(UNRAS) Bengkulu. Teknik pengambilan sampel yang digunakan dalam penelitian ini adalah metode sensus, yaitu mengambil seluruh populasi sebagai sampel penelitian. Berdasarkan jumlah populasi maka sampel dalam penelitian ini berjumlah 80 responden. Variabel penelitian terdiri dari variabel bebas yaitu keadilan distributif, keadilan prosedural, dan keadilan interaksional, variabel terikat adalah Employee Engagement, dan variabel moderasi adalah etos kerja Islam. Analisis data dalam penelitian ini menggunakan analisis regresi hirearki. Hasil penelitian ini membuktikan bahwa Distributive Justice berpengaruh positif signifikan terhadap Employee Engagement, Procedural Justice berpengaruh positif signifikan terhadap Employee Engagement, Interactional Justice berpengaruh positif signifikan terhadap Employee Engagement, Etika Kerja Islami memoderasi pengaruh Distributive Justice pada Employee Engagement, Islamic Work Ethics memoderasi pengaruh Keadilan Prosedural terhadap Employee Engagement dan Islamic Work Ethics memoderasi pengaruh Interactional Justice terhadap Employee Engagement.

Kata Kunci: Keadilan distributif, keadilan prosedural, keadilan interaksional, employee engagement dan etika kerja islam

\section{PENDAHULUAN}

Suksesnya suatu perusahaan tergantung pada kinerja karyawannya. Salah satu hal yang bisa menjadi kunci sukses adalah employee engagement. Perusahaan yang memiliki employee engagement kuat cenderung dapat bekerja lebih baik dan memberikan hasil kerja yang lebih baik pula. Dalam kurun waktu 10 tahun terakhir, istilah employee engagement muncul sebagai isu penting bagi dunia bisnis terutama pada iklim yang berangsur-angsur bangkit dari krisis ekonomi global (Andrew \& Sofian, 2012). Ketika karyawan merasakan terikat terhadap pekerjaannya, mereka akan merasa terdorong untuk berusaha mencapai tujuan yang menantang, ingin berhasil, dan memiliki komitmen pribadi untuk mencapai tujuantujuan organisasi (Bakker \& Leiter, 2010).

Markos \& Sridevi (2010) dan Lee dkk. (2017) menjelaskan employee engagement mengacu pada tingkat motivasi yang tinggi untuk berkinerja baik di tempat kerja, dikombinasikan dengan hasrat untuk bekerja dan perasaan dengan tim dan organisasi. Gupta \& Kumar (2013) menjelaskan bahwa organisasi yang berharap untuk mencapai keunggulan kompetitif melalui employee management akan paling berhasil dengan menggabungkan dan memasukkan employee management dalam proses manajemen kinerja.

Saks (2006) mengungkapkan bahwa tingkat engagement yang lebih besar dapat muncul ketika pegawai memiliki persepsi keadilan yang tinggi. Keadilan organisasi sebagai suatu konsep keseimbangan dalam memperlakukan pegawai diharapkan mampu diterapkan oleh organisasi dengan tujuan memicu tumbuhnya suatu rasa keterlibatan dalam pekerjaan. Keadilan organisasi memiliki tiga dimensi yaitu keadilan distributif, keadilan prosedural, dan keadilan interaksi.

Pertama adalah keadilan distributif. Simpson \& Kaminski (2007) menyatakan keadilan distributif mengacu pada keadilan yang dirasakan dari alokasi hadiah dalam suatu organisasi, seperti tingkat upah dan tunjangan mereka saat ini. Kreitner \& Kinicki (2018) menjelaskan bahwa keadilan distributif adalah suatu keadilan sumber daya dan imbalan penghargaan, mencerminkan keadilan yang dirasakan mengenai bagaimana sumber daya tersebut didistribusikan dan di alokasikan. Kesimpulan yang dapat ditarik 
berdasarkan penjelasan di atas adalah bahwa keadilan distributif mengacu pada keadilan dari tingkat bawah, yang mencakup masalah penggajian, promosi, maupun pemecatan.

Robbins \& Judge (2017) menyatakan keadilan distributif adalah keadilan jumlah imbalan yang dirasakan di antara individuindividu, seperti gaji dan pengakuan yang diterima karyawan. Colquitt (2001) menyatakan keadilan distributif atau keadilan imbalan yang cukup, yaitu karyawan menerima imbalan yang sama dengan karyawan lainnya yang diberikan sebagai pengganti jasa setelah menyelesaikan pekerjaan. Adanya keadilan yang diberikan perusahaan pada setiap karyawan tersebut, karyawan memberikan loyalitasnya dalam bekerja, produktifitas, dan tanggung jawab dalam setiap menjalankan pekerjaannya di perusahaan. Dari beberapa pernyataan sebelumnya dapat disimpulkan bahwa keadilan distributif merupakan rasa adil yang diterima karyawan dalam bentuk rewards atas kinerja yang telah diberikan. Karyawan akan merasa dihargai dan memberikan kinerja terbaik untuk perusahaan.

Beberapa penelitian terdahulu menyatakan bahwa keadilan distributif berpengaruh terhadap employee engagement. employee engagement berkaitan untuk semua jenis pekerjaan yang menggambarkan bagaimana kemampuan kapasitas karyawan untuk memecahkan masalah yang berhubungan dengan manusia dan bagaimana mengembangkan layanan yang inovatif. Bagaimana respon karyawan mengenai kebijakan organisasi, praktek, dan struktur dapat memengaruhi potensi karyawan terhadap employee engagement yang ada dalam diri karyawan (Bakker dkk., 2011).

Menurut Desyani \& Nurtjahjanti (2015) salah satu bentuk kebijakan organisasi yang dapat memenuhi kebutuhan karyawan tersebut dapat berupa keadilan distributif. Penelitian Alvi \& Abbasi (2012), Gupta \& Kumar (2013), dan Ghosh dkk.
(2014) membuktikan keadilan distributif berpengaruh positif signifikan employee engagement. Pengaruh keadilan distributif terhadap employee engagement juga dibahas oleh beberapa penelitian terdahulu oleh Singh \& Choundhary (2018), Pieters (2018), Herminingsih (2017), Lamprakis dkk. (2018), dan Jain \& Rajput (2017).

Selanjutnya adalah keadilan prosedural. Colquitt (2001) menjelaskan bahwa individu tidak hanya mengevaluasi distribusi hasil, namun juga mengevaluasi prosedur untuk melakukan alokasi tersebut. Al-Zu'bi (2010) memberikan pernyataan bahwa, "procedural justice refers to participants' perceptions about the fairness of the rules and procedures that regulate a process." Tyler \& Blader (2000) menjelaskan bahwa, "procedural justice is about optimistic about the ability of social authorities to bridges differences in interests and values, and find resolutions that the parties to a dispute will accept."

Akram dkk. (2017) menyatakan keadilan prosedural sangat membantu para manajer dan perusahaan dalam memahami dan mengetahui faktor-faktor yang dapat meningkatkan employee engagement para karyawan. Menurut Margaretha \& Santosa (2012) fokus keadilan prosedural adalah pada perhatian karyawan yaitu bagaimana prosedur untuk membuat keputusan tersebut dapat dilaksanakan. Sama seperti yang dikemukakan Marri dkk. (2013), keadilan prosedural mengacu pada keadilan prosedur untuk membuat keputusan.

Pada penelitian sebelumnya yang dilakukan oleh Saks (2006) yang menduga bahwa keadilan distributif dan prosedural menjadi prediktor terbentuknya employee engagement dalam organisasi. Hasil penelitian tersebut akhirnya menunjukkan keadilan prosedural memprediksi terjadinya organizational engagement. Selanjutnya pada penelitian Margaretha dan Santosa (2012) diperoleh hasil yang menunjukkan bahwa Keadilan Prosedural dan distributif menjadi 
prediktor dari employee engagement. Dengan kata lain, kedua jenis keadilan tersebut menjadi antesenden dari konstruk employee engagement dalam organisasi. Alvi \& Abbasi (2012), Gupta \& Kumar (2013), dan Ghosh dkk. (2014) membuktikan semakin tinggi keadilan prosedural akan meningkatkan employee engagement. Pengaruh keadilan prosedural terhadap employee engagement juga dibahas oleh beberapa penelitian terdahulu oleh Mlik dkk. (2018) dan Pan dkk. (2018).

Menurut Tjahjono (2008) persepsi keadilan prosedural lebih kuat menjelaskan outcomes organisasional berupa sikap individu terhadap organisasi. Keadilan prosedural (procedural justice) adalah keadilan yang dirasakan dari proses yang digunakan untuk menentukan distribusi penghargaan. (Greenberg \& Baron, 2003). Semakin besar keterlibatan anggota dalam pembuatan keputusan organisasi maka penerimaan mereka pada keputusan organisasi akan semakin besar. Hal ini yang mempengaruhi mereka semakin kuat dalam mengidentifikasi dan melibatkan diri kedalam organisasi (Greenberg \& Baron, 2003).

Dimensi ketiga dari keadilan organisasi adalah keadilan interaksi. Bies dan Moag (1986, dalam Ghosh dkk., 2014) telah menyarankan interactional justice sebagai dimensi ketiga dari organizational justice. Interactional justice lebih kepada mengevaluasi apakah seseorang merasa diperlakukan adil oleh rekan kerja dan supervisor secara hormat dan bermartabat (Gupta \& Kumar, 2013). Menurut Bies \& Moag (1986, dalam Ghosh dkk., 2014) interactional justice mengacu pada kualitas proses interpersonal dan treatment yang dirasakan oleh individu serta sejauh mana alasan di balik hasil yang dijelaskan atas kebijakan yang diberikan.
Dai \& Xie (2016) menyatakan kebanyakan peneliti tidak mempelajari keadilan interaksional secara khusus, karena keadilan interaksional dianggap sebagai bagian dari keadilan prosedural. Ando \& Matsuda (2010) menjelaskan bahwa keadilan interaksi didefinisikan sebagai perasaan karyawan tentang bagaimana mereka diperlakukan dalam proses pelaksanaan prosedur. Ketika karyawan merasa bahwa mereka diperlakukan dengan adil oleh para pemimpin mereka, mereka akan merasa bergairah dan memiliki moral yang tinggi.

Para peneliti berpendapat bahwa keadilan interaksional berkaitan dengan sifat perawatan yang diterima oleh karyawan ketika penyelia/manajer membuat keputusan. Untuk meningkatkan perawatan ini, manajer diharapkan untuk memberikan penjelasan yang cukup mengenai keputusan yang diambil dan mengomunikasikan informasi yang relevan dengan hormat dan sensitif. Colquitt (2001) menyelidiki validitas konstruk keadilan interaksional dan menawarkan bahwa keadilan interaksional harus dibagi lagi untuk mencakup keadilan interpersonal dan informasi.

Durrani (2017) dan Karam dkk. (2019) menyatakan hubungan interpersonal di tempat kerja merupakan faktor yang sangat penting bagi kesejahteraan karyawan dan pencapaian pekerjaan yang bermakna. Salinero dkk. (2019) menyatakan dari berbagai temuan ini mengubah keadilan interaksional menjadi variabel yang sangat menarik untuk dipertimbangkan saat mempromosikan organisasi yang berkelanjutan.

Oleh karena itu, manajer harus menyadari aspek relasional dalam organisasi mereka untuk mengatur iklim sosial yang positif. Pengaruh keadilan interaksional terhadap employee engagement juga dibahas oleh beberapa penelitian terdahulu oleh Agustina (2016), Akram dkk. (2019), Akoh \& Amah (2016), Lamprakis dkk. (2018), Alvi \& Abbasi (2012), dan Seleem dkk. (2016). 
Selain employee engagement, penelitian tentang keadilan dalam organisasi banyak dikaitkan dengan etika kerja. Salah satu etika kerja yang belum banyak diteliti adalah etika kerja Islam (Rokhman, 2015). Ali \& Abdullah (2008) menyatakan etika Islam adalah prinsip benar dan salah yang seharusnya dilakukan manusia berdasarkan Al-Quran dan seperti yang dilakukan dalam kehidupan Nabi besar Muhammad SAW. Ali (1998) menyatakan etika kerja Islam adalah konsep etika yang didasarkan pada ajaran dan prinsip Islam yang mempercayai keyakinan. Menurut Haroon dkk. (2012), etos kerja Islami bersifat komprehensif, realistis, dan moderat. Etika dalam Islam bukan hanya moralitas agama dalam tindakan tertentu tetapi juga mencakup semua segi kehidupan baik secara fisik, spiritual, moral, atau bahkan dalam bentuk duniawi seperti intelektual, emosional, individu, dan kolektif.

Kumar dan Rose (2010) menjelaskan bahwa "the IWE is analogous to the concept of Islam Hadhari that emphasizes cooperation in work, and consultation is seen as a way of overcoming obstacles and avoiding mistakes to meet one's needs and establish equilibrium in one's individual and social life." Definisi tersebut menjelaskan bahwa IWE adalah analog dengan konsep Islam yang menekankan kerjasama dalam pekerjaan, dan konsultasi dipandang sebagai cara mengatasi rintangan dan menghindari kesalahan untuk memenuhi kebutuhan seseorang dan membangun keseimbangan dalam kehidupan individu dan sosial seseorang.

Yousef (2001) menemukan bahwa individu yang cenderung percaya pada etika kerja islam maka kinerjanya lebih tinggi. Berdasarkan pendapat di atas maka orangorang yang memiliki tingkat penghayatan religiusitas yang tinggi apabila mendapat tekanan atau gangguan-gangguan yang tidak menyenangkan yang berasal dari luar diri seseorang tidak akan begitu berpengaruh pada employee engagement dan menjadikan hal tersebut untuk bisa lebih maju dalam bekerja.

Penelitian yang menghubungkan keadilan organisasi dan etika kerja Islam kurang mendapat perhatian oleh para ahli. Penelitian sebelumnya menunjukkan adanya hubungan yang erat antara keadilan organisasi dengan etika kerja. Misalnya, Greenberg (1993) menemukan bahwa karyawan yang merasa diperlakukan tidak adil maka berusaha untuk mengambil asset perusahaan sebagai usaha untuk menyeimbangkan perlakuan ketidakadilan distribusi sumberdaya yang mereka terima. Lebih lanjut, Trevino \& Weaver (2001) menemukan bahwa ketidakadilan yang sdirasakan oleh karyawan akan menimbulkan keinginan karyawan untuk mencari kesempatan untuk meningkatkan kesejahteraan mereka sendiri, meskipun mereka nilai tidak etis tetapi tetap mereka lakukan.

Beberapa penelitian telah dilakukan untuk mencari pengaruh atau hubungan antar isu-isu terkait employee engagement, keadilanorganisasi dan etikakerja Islam. Hasil penelitian Rasheed dkk. (2013) membuktikan keadilan prosedural berpengaruh positif terhadap employee engagement. Hasil penelitian penelitian Gupta \& Kumar (2013) dan Gosh dkk. (2014) juga membuktikan keadilan distributif berpengaruh positif terhadap employee engagement. Ramalu \& Rashid (2017) dan Salmabadi dkk. (2015) membuktikan bahwa etika kerja Islam berpengaruh signifikan terhadap employee engagement.

Pengaruh keadilan distributif terhadap employee engagement melalui etika kerja islam juga dibahas oleh beberapa penelitian terdahulu oleh Khan dkk. (2013), Yousef (2000), Mohammad dkk. (2016), Rokhman \& Hassan (2012), dan Mehmood dkk. (2018). Penelitian Khan dkk. (2015) membuktikan etika kerja Islam yang rendah mampu 
memoderasi hubungan positif keadilan prosedural dengan intensi turnover dan etika kerja Islam yang tinggi memoderasi hubungan negatif dengan intensi turnover.

Ghosh dkk. (2017) menyatakan bahwa keadilan interaksional memiliki pengaruh positif terhadap employee'work engagement dan peran moderasi etika kerja Islam memiliki hubungan positif antara organizational justice, organizational citizenship behavior, dan employee' work engagement. Pengaruh keadilan prosedural terhadap employee engagement melalui etika kerja Islam juga dibahas oleh beberapa penelitian terdahulu oleh Rokhman (2010), Amilin dkk. (2018), dan Ajmal \& Irfan (2014). Sedangkan pengaruh keadilan interaksional terhadap employee engagement melalui etika kerja Islam juga dibahas oleh beberapa penelitian terdahulu oleh Rokhman \& Hassan (2012), Malik dkk. (2018), Rana dkk. (2018), dan Durrani (2017).

Didasari dengan banyaknya penelitian terdahulu yang menganalisis tentang keadilan organisasi dan employee engagement akan tetapi masih sangat sedikit yang mengkaitkan dengan etika kerja Islam maka penelitian ini memberikan kebaruan dengan menganalisis pengaruh keadilan organisasi yang terdiri dari keadilan distributive, keadilan proseduran dan keadilan interaksional terhadap employee engagement serta pengaruh moderasi etika kerja Islam terhadaphubungan antara keadilan organisasi dan employee engagement dengan susunan hipotesis sebagai berikut:

H1: Terdapat pengaruh positif keadilan distributif terhadap employee engagement

$\mathrm{H} 2$ : Terdapat pengaruh positif keadilan prosedural terhadap employee engagement

H3: Terdapat pengaruh positif keadilan prosedural terhadap employee engagement
H4: Etika kerja Islam memoderasi pengaruh keadilan distributif terhadap employee engagement

H5: Etika kerja Islam memoderasi pengaruh keadilan prosedural terhadap employee engagement

H6: Etika kerja Islam memoderasi pengaruh keadilan interaksional terhadap employee engagement

\section{METODE PENELITIAN}

Analisis dalam penelitian ini menggunakan metode kuantitatif untuk menganalisis signifikansi hubungan antara variabel independen dan variabel dependen. Populasi dalam penelitian ini adalah seluruh pegawai tetap Universitas Ratu Samban. Adapun teknik pengambilan sampel dalam penelitian ini adalah total sampling. Besaran sampel dalam penelitian berjumlah 80 karyawan tetap. Sehingga pada penelitian ini menggunakan total sampling, yang di mana total sampling adalah teknik pengambilan sampel di mana jumlah sampel sama dengan populasi.

Teknik analisis data yang digunakan dalam penelitian ini adalah analisis regresi hirarki, dengan bantuan program SPSS. Analisis regresi hirarki adalah teknik statistik yang digunakan untuk mengetahui pengaruh dari variabel moderasi (Islamic work ethics) terhadap hubungan antara variabel independen (distributive justice, procedural justice, dan interactional justice) dan variabel dependen (employee engagement) Ghozali (2006), Variabel yang akan memperkuat atau memperlemah hubungan antara variabel independen lainnya terhadap variabel dependen variabel. Berikut adalah langkahlangkah analisis dalam persamaan regresi hirarki yang digunakan dalam penelitian ini.

1. Persamaan Analisis

$$
\begin{aligned}
& Y=a+\beta_{1} X_{1}+\beta_{2} X_{2}+e \\
& Y=a+\beta_{1} X_{1}+\beta_{2} X_{2}+\beta_{3} X_{1} * X_{3}+\beta_{4} X_{2} * X_{3}+e
\end{aligned}
$$


Keterangan:

$\mathrm{Y}=$ Employee Engagement

$\mathrm{X}_{1}=$ Distributive Justice

$\mathrm{X}_{2}=$ Procedural Justice

$\mathrm{X}_{3}=$ Interactional Justice

$\mathrm{X}_{4}=$ Islamic Work Ethics

$\mathrm{a}=$ Konstanta

$\beta=$ Koefisien Regresi

$\mathrm{e}=$ Kesalahan

2. Merumuskan hipotesis penelitian

Ho $=$ Tidak ada pengaruh variabel $\mathrm{X}$ terhadap Y.

$\mathrm{Ha}=$ Ada pengaruh variabel $\mathrm{X}$ terhadap Y.

3. Menghitung nilai statistik $t$ dan taraf signifikansinya

4. Menentukan taraf signifikansi standar sebesar 5\% $(0,05)$.

5. Keputusan pengujian

- Apabila nilai taraf signifikansi yang dihasilkan lebih besar dari 0,05, maka Ho diterima, artinya tidak ada pengaruh.

- Apabila nilai taraf signifikansi yang kurang dari 0,05, maka Ho ditolak, maka ada pengaruh.

\section{Definisi Operasional Variabel}

Definisi operasional adalah petunjuk tentang bagaimana sebuah variabel diukur, oleh karena itu peneliti dapat mengetahui baik atau buruknya dari pengukuran tersebut. Dalam penelitian ini definisi operasional dapat dijabarkan sebagai berikut.

\section{Keadilan distributif}

Menurut Cropanzano dkk. (2007) menyebutkan bahwa keadilan distributif terdiri dari tiga indikator yaitu sebagai berikut:

1. Keadilan yaitu menghargai karyawan berdasarkan kontribusinya.

2. Persamaan yaitu menyediakan kompensasi bagi setiap karyawan yang secara garis besar sama.
3. Kebutuhan yaitu menyediakan benefit atau keuntungan berdasarkan pada kebutuhan personal seseorang.

\section{Keadilan Prosedural}

Pengukuran variabel keadilan prosedural menggunakan pertanyaanpertanyaan yang dikembangkan oleh Colquit (2001). Indikator keadilan prosedural diukur dengan menggunakan tujuh item sebagai berikut Colquit (2001):

1. Dapat mengemukakan pandangan selama prosedur dilakukan.

2. Dapat memengaruhi keputusan yang dibuat dalam prosedur-prosedur tersebut.

3. Prosedur dilaksanakan secara konsisten oleh manajemen.

4. Prosedur bebas dari kepentingan pihak luar.

5. Pelaksanaan prosedur dilaksanakan berdasarkan data yang akurat.

6. Dapat melakukan banding atas keputusan yang diambil berdasarkan proses tersebut.

7. Prosedur menjunjung tinggi moral dan etika.

\section{Keadilan Interaksional}

Colquitt (2001) menjelaskan untuk mengukur skala keadilan interaksional terdiri dari 4 item tentang keadilan interaksional dan 5 item tentang keadilan informasional. Metode penilaian menggunakan skala Likert. Indikator-indikator tersebut adalah:

1. Kesopanan: Indikator ini diukur dengan menggunakan 1 item yaitu Atasan saya memperlakukan saya dengan cara yang sopan.

2. Bermartabat: Indikator ini diukur dengan menggunakan 1 item yaitu Atasan saya memperlakukan saya dengan penuh martabat.

3. Hormat: menunjukkan penilaian mengenai sikap hormat yang ditunjukkan atasan kepada bawahan. Indikator ini diukur dengan menggunakan 1 item 
yaitu Atasan saya memperlakukan saya dengan rasa hormat.

4. Kepantasan kata-kata: Indikator ini diukur dengan menggunakan 1 item yaitu Atasan saya menahan diri untuk tidak berkata-kata atau berkomentar yang tidak pantas.

5. Kejujuran: Indikator ini diukur dengan menggunakan 1 item yaitu Atasan saya jujur dalam berkomunikasi.

6. Pembenaran: Indikator ini diukur dengan menggunakan 1 item yaitu Atasan saya menjelaskan peraturan/prosedur secara menyeluruh.

7. Masuk akal: Indikator ini diukur dengan menggunakan 1 item yaitu Penjelasan atasan saya terkait peraturan/prosedur masuk akal.

8. Tepat waktu: Indikator ini diukur dengan menggunakan 1 item yaitu Atasan saya berkomunikasi secara rinci kapanpun diperlukan.

9. Spesifik: Indikator ini diukur dengan menggunakan 1 item yaitu Atasan saya menyesuaikan komunikasinya terhadap kebutuhan khusus individu.

\section{Employee Engagement}

Variabel employee engagement diukur dengan indikator yang telah dikembangkan Schaufeli \& Bakker (2006). Indikatorindikator yang digunakan dalam variabel Employee Engagement adalah Schaufeli \& Bakker (2006):

1. Vigor, tingginya tingkat energi dan ketahanan mental saat bekerja, kemampuan untuk menginvestasikan usaha dalam pekerjaan dan tekun dalam menghadapi kesulitan. Indikator di atas dapat diukur dengan menggunakan enam item, yaitu:

- Di tempat kerja saya, saya merasa penuh dengan energi.

- Pada pekerjaan saya, saya merasa kuat dan bersemangat.
- Ketika saya bangun di pagi hari, aku merasa seperti pergi bekerja.

- $\quad$ Saya bisa terus bekerja untuk waktu yang sangat lama pada suatu waktu.

- Pada pekerjaan saya, saya sangat tangguh secara mental.

- Di tempat kerja saya, saya selalu bertahan, bahkan ketika sesuatu tidak berjalan dengan baik.

2. Dedication, menunjukkan ketertiban seseorang dalam pekerjaan, memiliki rasa penting bagi organisasi, antusias, inspirasi, bangga, dan tantangan. Indikator di atas dapat diukur dengan menggunakan lima item, yaitu:

- Saya menemukan pekerjaan yang saya lakukan penuh makna dan tujuan.

- Saya antusias perihal pekerjaan saya.

- Pekerjaan saya menginspirasi saya.

- $\quad$ Saya bangga pada pekerjaan yang saya lakukan.

- Bagi saya, pekerjaan saya adalah menantang

3. Absorption, ditandai dengan sepenuhnya terkonsentrasi dan dengan senang hati dalam bekerja, di mana waktu berlalu dengan cepat, serta dapat memisahkan kesulitan pribadi dengan pekerjaan. Indikator di atas dapat diukur dengan menggunakan enam item, yaitu:

- Waktu berlalu begitu cepat ketika saya sedang bekerja

- Ketika saya bekerja, saya lupa segala sesuatu yang lain di sekitar saya.

- Saya merasa senang ketika saya bekerja intens.

- Saya tenggelam dalam pekerjaan saya.

- Saya terbawa ketika saya sedang bekerja. 
- Sulit untuk melepaskan diri dari pekerjaan saya.

\section{Etika Kerja Islam}

MenurutKhadijah dkk. (2015) ada empat indikator dalam konsep etika kerja Islam yaitu:

1. Berusaha (effort), seorang muslim diwajibkan untuk berusaha dan bekerja untuk memenuhi kebutuhan dirinya, keluarga dan masyarakat. Islam sangat menjunjung tinggi produktifitas kerja karena akan meminimalisir berbagai permasalahan sosial dan ekonomi. Indikator di atas dapat diukur menggunakan empat item, yaitu:

- Kemalasan adalah buruk

- Dedikasi terhadap pekerjaan adalah baik

- Bekerja dengan baik bermanfaat bagi diri sendiri dan orang lain

- Keadilan dan kenyamanan di tempat kerja merupakan kondisi penting bagi kesejahteraan karyawan

2. Persaingan (competition), seorang pekerja harus mampu bersaing dengan karyawan lain secara fair dan jujur dengan niat fastabiqul khairot (berlomba untuk mencapai kebajikan). Indikator di atas dapat diukur menggunakan empat item, yaitu:

- Menghasilkan lebih dari cukup untuk memenuhi kebutuhan seseorang akan memberikan kemakmuran bagi karyawan secara keseluruhan

- Seseorang harus melaksanakan pekerjaan dengan kemampuan yang terbaik

- Bekerja bukan merupakan tujuan, tetapi bekerja merupakan sarana untuk pengembangan pribadi dan hubungan sosial

- $\quad$ Hidup tidak berarti tanpa bekerja
3. Keterbukaan (transparency), keterbukaan terhadap berbagai kegiatan yang ada dalam organisasi. Indikator di atas dapat diukur menggunakan empat item, yaitu:

- Lebih banyak waktu luang (untuk santai-santai) adalah tidak baik

- Hubungan manusia dalam organisasi harus mendapatkan perhatian yang besar

- Bekerja memungkinkan seseorang mengendalikan keadaan hidup

- Kreatifitas kerja merupakan sumber kebahagiaan dan keberhasilan

4. Moralitas (Morality), segala bentuk kegiatan harus berdasarkan etika Islam, karena agama Islam tidak mengenal dikotomis antara urusan keduniaan dan agama. Indikator di atas dapat diukur menggunakan lima item, yaitu:

- Siapa saja yang bekerja akan lebih dapat mencapai kemajuan dalam kehidupan

- Bekerja memberikan kesempatan untuk mandiri

- $\quad$ Seseorang yang sukses adalah orang yang dapat memenuhi target di dalam pekerjaannya

- Seseorang seharusnya terus bekerja keras untuk memenuhi tanggung jawabnya

- Nilai kerja lebih ditentukan oleh niatnya daripada oleh hasil kerjanya

\section{HASIL DAN PEMBAHASAN}

\section{Hasil Uji Analisis Regresi Hirarki Tahap 1}

Tahap pertama dari regresi hirarki berganda dalam penelitian ini adalah menguji tiap variabel independen yaitu keadilan distributif (X1), keadilan prosedural (X2), keadilan interaksional (X3), dan variabel moderasi etika kerja Islam (M) terhadap variabel dependen yaitu employee engagement. 
Tabel 1. Hasil Uji Analisis Regresi Hirarki Tahap 1.

\begin{tabular}{lcccc}
\hline \multicolumn{1}{c}{ Variabel } & Koefisien Regresi & t hitung & Sig. & Keterangan \\
\hline (Constant) & 1.020 & 2.328 & 0.023 & \\
Keadilan Distributif (X1) & 0.207 & 3.282 & 0.002 & H1 didukung \\
Keadilan Prosedural (X2) & 0.174 & 2.681 & 0.009 & H2 didukung \\
Keadilan Interaksional (X3) & 0.156 & 2.347 & 0.022 & H3 didukung \\
Etika Kerja Islam (M) & 0.226 & 2.761 & 0.007 & \\
F $_{\text {hitung }}$ & 13.175 & & & \\
Sig. F & 0.000 & & & \\
Adj. R Square & 0.381 & & & \\
\hline
\end{tabular}

Berdasarkan Tabel 1 dapat diketahui perumusan dari regresi linier berganda untuk estimasi pengaruh Keadilan Distributif, Keadilan Prosedural, dan Keadilan Interaksional terhadap Employee Engagement. Persamaan tersebut adalah sebagai berikut:

$\mathrm{Y}=0.207 \mathrm{X}_{1}+0.174 \mathrm{X}_{2}+0.156 \mathrm{X}_{3}+0.226 \mathrm{M}$

Berdasarkan hasil persamaan regresi tersebut, maka dapat diinterprestasikan koefisien regresi untuk variabel Keadilan Distributif (X1) adalah sebesar 0,207 (positif), Keadilan prossedural sebesar 0.174 (positif), dan Keadilan Interaksional sebesar 0.156 (positif). Nilai tersebut dapat diartikan apabila variabel Keadilan Distributif, Keadilan prossedural, dan Keadilan Interaksional meningkat maka besarnya Employee Engagement juga akan meningkat. Hasil uji Anova menghasilkan nilai F hitung sebesar 13,175 dengan tingkat signifikansi sebesar 0,000. Pada tingkat signifikansi $(\alpha=5 \%)$, maka nilai signifikansi $0,000<$ 0,05 yang dapat disimpulkan bahwa model tersebut layak dan dapat digunakan untuk memprediksi employee engagement. Hasil analisis koefisien determinasi atau Ajudsted $R$ Square pada Tabel 1, adalah sebesar 0,381. Hasil ini dapat diartikan bahwa Keadilan Distributif, Keadilan Prosedural, Keadilan Interaksional, dan Etika Kerja Islam mampu menjelaskan perubahan employee engagement sebesar 38,1\%. Sedangkan sisanya $61,9 \%$ dijelaskan oleh variabel lain di luar penelitian.

\section{Hasil Uji Analisis Regresi Hirarki Tahap 2}

Tahap kedua dari regresi hirarki adalah menguji interaksi antara masing-masing variabel independen dan variabel moderasi (Keadilan Distributif*Etika Kerja Islam, Keadilan Interaksional*Etika Kerja Islam, dan Keadilan Prosedural*Etika Kerja Islam) terhadap Employee Engagement.

Tabel 2. Hasil Uji Analisis Regresi Hirarki Tahap 2

\begin{tabular}{lccccc}
\hline $\begin{array}{c}\text { Variabel } \\
\text { (Constant) }\end{array}$ & $\begin{array}{c}\text { Koefisien Regresi } \\
1.619\end{array}$ & $\begin{array}{c}\text { t hitung } \\
0.348\end{array}$ & p-value & Sig. & Keterangan \\
\hline $\mathrm{X} 1$ & 0.144 & 0.058 & 0.205 & .015 & Signifikan \\
$\mathrm{X} 2$ & 0.212 & 0.057 & 0.320 & .000 & Signifikan \\
$\mathrm{X} 3$ & 0.145 & 0.061 & 0.207 & .021 & Signifikan \\
$\mathrm{X} 1 * \mathrm{M}$ & 0.218 & 0.075 & 0.243 & .005 & H4 didukung \\
$\mathrm{X} 2 * \mathrm{M}$ & 0.251 & 0.101 & 0.218 & .016 & H5 didukung \\
$\mathrm{X} 3 * \mathrm{M}$ & 0.181 & 0.082 & 0.187 & .030 & H6 didukung \\
$\mathrm{F}_{\text {hitung }}$ & 1121 & & & & \\
Sig. F & 0.000 & & & & \\
Adj. R Square & 0.507 & & & & \\
\hline
\end{tabular}


Berdasarkan Tabel 2 dapat diketahui semua interaksi atau moderasi adalah signifikan. Hasil ini dapat diartikan bahwa etika kerja Islam berhasil memoderasi pengaruh keadilan distributif, keadilan prosedural, dan keadilan interaksional terhadap employee engagement. Model regresi yang terbentuk adalah:

$\mathrm{Y}=0,218 \mathrm{X}_{1} \mathrm{M}+0,251 \mathrm{X}_{2} \mathrm{M}+0.181 \mathrm{X}_{3} \mathrm{M}$

Berdasarkan parameter persamaan regresi yang terdapat pada Tabel 2, maka dapat diinterpretasikan bahwa etika kerja Islam mempengaruhi serta memperkuat hubungan antara keadilan distributif terhadap employee engagement dengan koefisien regresi sebesar 0,218 (positif), keadilan prosedural terhadap employee engagement dengan koefisien regresi sebesar 0,251 (positif), dan keadilan interaksional terhadap employee engagement dengan koefisien regresi sebesar 0,181 (positif). Hasil ini dapat diartikan bahwa apabila etika kerja Islam meningkat maka Pengaruh hubungan antara keadilan distributif, prosedural, dan keadilan interaksional terhadap employee engagement juga akan meningkat. Hasil uji Anova menghasilkan nilai $\mathrm{F}$ hitung sebesar 14,521 dengan tingkat signifikansi sebesar 0,000. Pada tingkat signifikansi $(\alpha=5 \%)$, maka nilai signifikansi $0,000<$ 0,05 yang dapat disimpulkan bahwa model tersebut layak dan dapat digunakan untuk memprediksi hubungan antara keadilan distributif, keadilan prosedural, dan keadilan interaksional terhadap employee engagement dengan etika kerja Islam sebagai variabel moderasi.

Taraf signifikansi yang dihasilkan oleh variabel $\mathrm{X} 1 * \mathrm{M}$ adalah sebesar 0,005 . Pada tingkat signifikansi $(\alpha=5 \%)$, maka nilai signifikansi $0,005<0,05$ yang dapat disimpulkan bahwa etika kerja Islam sebagai variabel moderasi dapat dinyatakan sebagai variabel moderasi untuk memprediksi hubungan antara keadilan distributif terhadap employee engagement.
Taraf signifikansi yang dihasilkan oleh variabel $\mathrm{X} 2 * \mathrm{M}$ adalah sebesar 0,016. Pada tingkat signifikansi $(\alpha=5 \%)$, maka nilai signifikansi $0,005<0,16$ yang dapat disimpulkan bahwa etika kerja Islam sebagai variabel moderasi dapat dinyatakan sebagai variabel moderasi untuk memprediksi hubungan antara keadilan prosedural terhadap employee engagement.

Taraf signifikansi yang dihasilkan oleh variabel $\mathrm{X} 3 * \mathrm{M}$ adalah sebesar 0,03 . Pada tingkat signifikansi ( $\alpha=5 \%$ ), maka nilai signifikansi $0,03<0,05$ yang dapat disimpulkan bahwa etika kerja Islam sebagai variabel moderasi dapat dinyatakan sebagai variabel moderasi untuk memprediksi hubungan antara keadilan interaksional terhadap employee engagement.

Hasil analisis koefisien determinasi atau Adjusted R Square pada Tabel 2, adalah sebesar 0,507. Hasil ini dapat diartikan bahwa keadilan distributif, keadilan prosedural, dan keadilan interaksional yang dimoderasi oleh etika kerja Islam mampu menjelaskan perubahan employee engagement adalah sebesar 50,7\%. Sedangkan sisanya $49,3 \%$ dijelaskan oleh variabel lain di luar penelitian. Dari Tabel 2 terlihat bahwa sebelum ada moderasi nilai Adjusted R Square adalah sebesar 0,381 atau 38,1\%, namun setelah adanya variabel moderasi, nilai Adjusted R Square meningkat menjadi sebesar 0,507 atau $50,7 \%$. Dengan peningkatan ini maka etika kerja Islam mampu memoderasi dan meningkatkan pengaruh antara keadilan distributif, keadilan prosedural, dan keadilan interaksional terhadap employee engagement.

\section{PEMBAHASAN}

Hasil penelitian ini menunjukkan bahwa keadilan distributif berpengaruh positif signifikan terhadap employee engagement. Hal ini berarti bahwa semakin baik penerapan keadilan distributif akan meningkatkan employee engagement dan sebaliknya apabila 
semakin buruk penerapan keadilan distributif akan menurunkan employee engagement. Hasil ini menunjukkan bahwa apabila persepsi karyawan UNRAS mengenai keseimbangan distribusi hasil organisasi berupa gaji, tunjangan dan bonus adalah meningkat maka employee engagement akan semakin tinggi.

Hasil ini sesuai dengan penelitian Desyani \& Nurtjahjanti (2015) terdapat pengaruh keadilan distributif terhadap employee engagement, dengan keadilan distributif memberikan sumbangan efektif sebesar $17,6 \%$ pada terbentuknya employee engagement. Penelitian Alvi \& Abbasi (2012), Gupta \& Kumar (2013), Ghosh dkk. (2014) membuktikan keadilan distributif berpengaruh positif signifikan employee engagement.

Hasil penelitian ini juga menunjukkan bahwa keadilan prosedural berpengaruh positif signifikan terhadap employee engagement. Hal ini berarti bahwa semakin baik penerapan keadilan prosedural akan meningkatkan employee engagement dan sebaliknya apabila semakin buruk penerapan keadilan prosedural akan menurunkan employee engagement. Hasil ini menunjukkan bahwa apabila persepsi karyawan UNRAS mengenai prosedur untuk melakukan alokasi distribusi hasil adalah baik maka employee engagement akan tinggi.

Hal ini berarti bahwa apabila karyawan UNRAS mempunyai persepsi yang baik mengenai prosedur penilaian kinerja yang melibatkan karyawan, konsisten, mempunyai informasi yang akurat, sesuai dengan etika dan standar moral, tidak mengandung kepentingan pihak tertentu dan terbuka terhadap koreksi dan masukan akan meningkatkan rasa keterikatan yang dimiliki pegawai, bersemangat dan melakukan aktivitas kerjanya dengan efektif serta pegawai tersebut memiliki keyakinan yang kuat untuk dapat menyelesaikan atau menangani setiap pekerjaannya dengan baik. Pengaruh dari persepsi keadilan pada berbagai macam hasil kerja mungkin hasil dari sebagian employee engagement. Di sisi lain, persepsi keadilan yang rendah kemungkinan disebabkan para karyawan menarik diri dan melepaskan diri mereka sendiri dari peran kerja mereka. Keadilan juga merupakan salah satu kondisi kerja dalam model engagement. Berkurangnya keadilan dapat memperburuk burnout (kelelahan) dan sementara persepsi positif keadilan dapat memperbaiki engagement (Saks, 2006).

Pada penelitian sebelumnya yang dilakukan oleh Saks (2006) yang menduga bahwa keadilan distributif dan keadilan prosedural menjadi prediktor terbentuknya employee engagement dalam organisasi. Hasil penelitian tersebut akhirnya menunjukkan keadilan prosedural memprediksi terjadinya organizational engagement. Selanjutnya pada penelitian Margaretha \& Santosa (2012) diperoleh hasil yang menunjukkan bahwa keadilan prosedural dan keadilan distributif menjadi prediktor dari employee engagement. Kebanggaan sebagai anggota organisasi akan memengaruhi employee engagement karena kebanggaan sebagai anggota organisasi membuat karyawan akan memandang apabila kesuksesan organisasi adalah kesuksesannya. Karyawan yang memiliki kebanggan yang tinggi akan cenderung memiliki engagement dengan pekerjaan mereka karena memandang hubungan mereka dengan organisasi saling menguntungkan (He \& Brown, 2013). Hasil ini sesuai penelitian Alvi \& Abbasi (2012), Gupta \& Kumar (2013), Ghosh dkk. (2014) membuktikan semakin tinggi keadilan prosedural akan meningkatkan employee engagement.

Hasil selanjutnya dalam penelitian ini menunjukkan bahwa keadilan interaksional berpengaruh positif signifikan terhadap employee engagement. Hal ini berarti bahwa semakin banyak interaksi yang dilakukan oleh sesama karyawan maka keadilan interaksional akan meningkatkan employee 
engagement dan sebaliknya apabila semakin buruk interaksinya maka akan menurunkan employee engagement. Hasil tersebut didukung oleh beberapa penelitian terdahulu seperti Agustina (2016; Akram dkk., 2019; Akoh \& Amah, 2016; Lamprakis dkk., 2918; Alvi \& Abbasi, 2012; Saleem dkk., 2016).

Penelitian ini juga menghasilkan bahwa etika kerja Islam memoderasi pengaruh keadilan distributif terhadap employee engagement. Hal ini berarti bahwa semakin baik etika kerja Islam akan meningkatkan hubungan keadilan distributif dan employee engagement dan sebaliknya apabila semakin buruk Etika Kerja Islam akan menurunkan hubungan keadilan distributif dan employee engagement. Hasil ini berarti apabila karyawan UNRAS mampu menerapkan nilainilai Islami dalam etika bekerja mereka akan meningkatkan pengaruh persepsi karyawan tentang keadilan distributif dalam organisasi terhadap employee engagement, dengan adanya etika kerja Islam yang semakin tinggi maka pengaruh keadilan distributif terhadap employee engagement akan semakin kuat. Hal tersebut didukung oleh beberapa penelitian terdahulu seperti Khan, dkk. (2013; Yousef, 2000; Mohammad dkk., 2016; Rokhman \& Hassan, 2012; Mehmood dkk., 2018).

Selanjutnya hasil penelitian ini menunjukkan bahwa etika kerja Islam memoderasi pengaruh keadilan prosedural terhadap employee engagement. Hal ini berarti bahwa semakin baik etika kerja Islam akan meningkatkan hubungan keadilan prosedural dan employee engagement dan sebaliknya apabila semakin buruk etika kerja Islam akan menurunkan hubungan keadilan prosedural dan employee engagement.

Trevino dkk. (2001) menjelaskan bahwa terdapat hubungan yang kuat antara perlakuan yang adil dengan etos. Studi mereka menunjukkan bahwa tindakan tidak etis menurun secara signifikan ketika karyawan percaya bahwa organisasi tempat mereka bekerja memperlakukan karyawan secara adil. Seorang karyawan muslim yang menerapkan etika kerja Islam dengan baik akan menjalankan kegiatan oprasional dalam perusahaannya penuh dengan nilainilai keadilan. Menurut Bouma dkk. (2003), individu yang menerapkan etos kerja Islam dengan sungguh-sungguh seharusnya memiliki kemungkinan yang kecil untuk merespon negatif perlakuan yang tidak adil.

Etika kerja Islam yang menekankan kerja kreatif dan inovatif sebagi sumber kebahagiaan dan prestasi. Hal tersebut sejalan dengan hasil penelitian Brown dkk. (2016) yang menunjukan bahwa keterikatan kerja akan semakin sikap positif bila dimiliki oleh karyawan dengan sikap religiusitas yang bekerja berdasarkan etika kerja Islam, karena seorang karyawan yang menyadari keterikatannya dalam bekerja akan berusaha meningkatkan pekerjaannya untuk kepentingan organisasi. Sedangkan penelitian Khan dkk. (2014) membuktikan etika kerja Islam yang rendah mampu memoderasi hubungan positif keadilan prosedural dengan intensi turnover dan etika kerja Islam yang tinggi memoderasi hubungan negatif dengan intensi turnover. Sebaliknya, keadilan prosedural berhubungan negatif dengan intensi turnover untuk etika kerja Islam yang rendah dan berhubungan positif dengan intensi turnover untuk etika kerja Islam yang rendah tinggi.

Hasil penelitian ini menunjukkan bahwa etika kerja Islam memoderasi pengaruh keadilan interaksional terhadap employee engagement. Hal ini berarti bahwa semakin baik etika kerja Islam akan meningkatkan hubungan Keadilan interaksional dan employee engagement dan sebaliknya apabila semakin buruk etika kerja Islam akan menurunkan hubungan keadilan interaksional dan employee engagement. Hasil ini berarti apabila karyawan UNRAS mampu menerapkan nilai-nilai Islami dalam etika bekerja mereka akan meningkatkan hubungan persepsi karyawan yang tinggi 
tentang tentang keadilan dalam organisasi mereka, dipastikan mereka merasa diwajibkan atau diharuskan untuk berlaku adil didalam memainkan peran mereka dengan memberi lebih besar melebih tingkat engagement.

Penelitian mengenai pengaruh etika kerja terhadap kinerja, selain yang dikemukakan oleh Weber (Ali,1988; AbuSaad,1998), juga dilakukan oleh beberapa peneliti lainnya, walaupun tidak dalam konteks kinerja sebenarnya. Cohen (1999) menguji model Randall \& Cote, dan membuktikan bahwa PWE berpengaruh signifikan terhadap keterlibatan kerja. Miller et al. (2001) menguji pengaruh etika kerja terhadap kepuasan kerja pada mahasiswa dan praktisi, dan membuktikan bahwa etika kerja berpengaruh signifikan terhadap kepuasan kerja. Hatcher (2002) menemukan pengaruh positif etika kerja terhadap keahlian instruktur. Pengaruh etika kerja islami terhadap performansi kerja, maka secara individual maupun kelembagaan, etika kerja staf pengajar harus ditingkatkan dan dipelihara. Menyelenggarakan programprogram pengembangan mental-spiritual secara pribadi, maupun kelompok merupakan salah satu solusi untuk mewujudkan kondisi tersebut, sementara secara organisasional, program-program berbasis kecerdasan emosional (Goleman, 2000) serta kecerdasan spiritual (Zohar \& Marshal, 2000) merupakan alternatif yang bisa dilakukan.

\section{SIMPULAN DAN SARAN}

Berdasarkan hasil analisis dan pembahasan yang telah disampaikan sebelumnya, dapat ditarik kesimpulan pada penelitian ini sebagai berikut:

1. Hasil yang diperoleh pada penelitian ini menunjukkan bahwa Keadilan Distributif memiliki pengaruh positif signifikan terhadap Employee Engagement. Hal ini berarti menunujukkan bahwa semakin baik penerapan Keadilan Distributif akan meningkatkan Employee Engagement dan sebaliknya apabila semakin buruk penerapan Keadilan Distributif akan menurunkan Employee Engagement. Hasil ini menunjukkan bahwa apabila persepsi karyawan UNRAS mengenai kesetaraan gaji, tunjangan dan bonus adalah baik maka Employee Engagement akan tinggi.

2. Hasil penelitian ini menunjukkan bahwa Keadilan Prosedural berpengaruh positif signifikan terhadap Employee Engagement. Hal ini berarti bahwa semakin baik penerapan Keadilan Prosedural akan meningkatkan Employee Engagement dan sebaliknya apabila semakin buruk penerapan Keadilan Prosedural akan menurunkan Employee Engagement. Hasil ini menunjukkan bahwa apabila persepsi karyawan UNRAS mengenai prosedur untuk melakukan alokasi distribusi hasil adalah baik maka Employee Engagement akan tinggi.

3. Hasil penelitian ini menunjukkan bahwa Keadilan Interaksional berpengaruh positif signifikan terhadap Employee Engagement. Hal ini berarti bahwa semakin baik penerapan Keadilan Interaksional akan meningkatkan Employee Engagement dan sebaliknya apabila semakin buruk penerapan Keadilan Interaksional akan menurunkan Employee Engagement. Hasil ini menunjukkan bahwa apabila persepsi karyawan UNRAS mengenai prosedur untuk melakukan interaksi dengan baik dan sesuai etika adalah baik maka Employee Engagement akan tinggi.

4. Hasil penelitian ini menunjukkan bahwa Etika Kerja Islam memoderasi pengaruh Keadilan Distributif terhadap Employee Engagement. Hal ini berarti bahwa semakin baik Etika Kerja Islam akan meningkatkan hubungan Keadilan Distributif dan Employee Engagement 
dan sebaliknya apabila semakin buruk Etika Kerja Islam akan menurunkan hubungan Keadilan Distributif dan Employee Engagement.

5. Hasil penelitian ini menunjukkan bahwa Etika Kerja Islam memoderasi pengaruh Keadilan Prosedural terhadap Employee Engagement. Hal ini berarti bahwa semakin baik Etika Kerja Islam akan meningkatkan hubungan Keadilan Prosedural dan Employee Engagement dan sebaliknya apabila semakin buruk Etika Kerja Islam akan menurunkan pengaruh Keadilan Prosedural terhadap Employee Engagement.

6. Hasil penelitian ini menunjukkan bahwa Etika Kerja Islam memoderasi pengaruh Keadilan Interaksional terhadap Employee Engagement. Hal ini berarti bahwa semakin baik Etika Kerja Islam akan meningkatkan hubungan Keadilan Interaksional dan Employee Engagement dan sebaliknya apabila semakin buruk Etika Kerja Islam akan menurunkan pengaruh Keadilan Interaksional terhadap Employee Engagement.

\section{IMPLIKASI MANAJERIAL}

UNRAS harus menciptakan kondisi persepsi keadilan organisasi yang diharapkan dapat mendorong terciptanya Employee Engagement yang dapat diciptakan di UNRAS yaitu Lingkungan kerja yang memiliki Keadilan Distributif, Prosedural dan Interaksional. Dengan diperolehnya keadilan tersebut maka pekerja akan berlaku adil pada organisasi, dengan cara membangun ikatan emosi yang mendalam pada organisasi, Lingkungan kerja yang melibatkan pekerja dalam pengambilan keputusan. Hal ini akan memengaruhi pekerja secara psikologis dan menganggap dirinya berharga bagi organisasi dan organisasi yang memperhatikan keseimbangan kehidupan kerja dan keluarga pekerja. Selain itu, UNRAS harus menciptakan dan menerapkan Etika Kerja Islam dalam kehidupan berorganisasi seperti peningkatan aspek pelayanan yang baik, kedisiplinan, dan kerajinan. Berdasarkan tiga aspek tersebut mereka sudah mampu menerapkan etika kerja secara Islami sesuai yang diharapkan.

Berdasarkan deskriptif variabel penelitian, diperoleh hasil bahwa Keadilan Distributif, Keadilan Prosedural, Keadilan Interaksional dan Etika Kerja Islam adalah sedang. Oleh karena itu, hasil penilaian deskriptif maka saran yang diberikan bagi pihak manajemen UNRAS untuk meningkatkan taraf keadilan distributif, keadilan prosedural dan keadilan interaksional.Peningkatankeadilan distributif dapat dilakukan dengan cara meningkatkan penilaian kinerja yang disesuaikan dengan kinerja karyawan, prestasi karyawan, dan perilaku karyawan di tempat kerja sedangkan peningkatan keadilan prosedural dapat dilakukan dengan cara setiap prosedur penilaian kinerja harus dilaksanakan secara konsisten dan melibatkan karyawan dan didasarkan dengan informasi, etika dan moral serta tidak mengandung kepentingan pihak tertentu, dan untuk peningkatan keadilan interaksional dapat dilakukan dengan cara setiap personal didalamnya melakukan interaksi dengan cara yang baik dan sesuai dengan etika yang berlaku baik dengan atasan maupun teman sejawat.

\section{REFERENSI}

Agustina, T. S. (2016). Organizational Justice, Employee Engagement dan Perceived Organizational Support pada Pt. Petrokimia Gresik. Conference on Management and Behavioral Studies, 383-394.

Ajmal, M. U., \& Irfan, S. (2014). Understanding teh Moderating Role Islamic Work Ethics between Job Stress and Work Outcomes. IOSR 
Journal of Business and Management, 16, 62-67.

Akoh, A., \& Amah, E. (2016). Interactional Justice and Employees'Commitment to Supervisor in Nigerian Health Sector. International Journal of Innovation and Economic Development, 2(5), 7-17.

Akram, T., Lei, S., Haider, M. J., Hussain, S. T., \& Puig, L. C. M. (2017). The effect of organizational justice on knowledge sharing: Empirical evidence from the Chinese telecommunications sector. Journal of Innovation and Knowledge, 2(3), 134-145.

Ali A. (1988). Scaling an Islamic work ethics. Journal of Social Psychology, 128(5), 575-83.

Ali A. J., \& Abdullah, A. O. (2008). Islamic Work Ethic: A Critical Review, Cross Cultural Management: An International Journal, 15(1), 5-19.

Alvi, A.K., \& Abbasi, A.S. (2012). Impact of Organizational Justice on Employee Engagement in Banking Sector of Pakistan. Middle-East Journal of Scientific Research, 12(5), 643-649.

Al-Zu'bi, H. A. (2010). A Study of Relationship Between Organizational Justice and Job Satisfaction. International Journal of Business and Management, 5(12), 102-109.

Ando, N., \& Matsuda, S. (2010) How Employees See Their Roles: The Effect of Interactional Justice and Gender. Journal of Service Science and Management, 3(2), 281-286.

Andrew, O. C., \& Sofian, S. (2012). Individual factors and work outcomes of employee engagement. ProcediaSocial and Behavioral Sciences, 40, 498-508.

Bakker, A. B., Albrecht, S. L., \& Leiter, M. P. (2011). Key questions regardinng work engagement. European Journal of Work and Organizational Psychology, 20(1), 4-28.

Bies, R. J., \& Moag, J. S. (1986). Interactional justice: Communications criteria of fairness. Research in negotiation in organizations, 1, 43-55.

Brown, D., Callen,A., \& Robinson, D. (2016). The Relationship Between Total Reward and Employee Engagement. London: NHS Employers.

Colquitt, J.A. (2001), On the dimensionality of organizational justice: a construct validation of a measure, Journal of Applied Psychology, 86(3), 386-400.

Cropanzano, R., Bowen, D. E., \& Gilliland, S. W. (2007). The management of organizational justice. Academy of management perspectives, 21(4), 3448.

Dai, L., \& Xie, H. (2016). Review and Prospect on Interactional Justice. Open Journal of Social Sciences, 4(1), 55-61.

Desyani, I. D., \& Nurtjahjanti, H. (2015). Hubungan Antara Keadilan Distributif Dengan Employee Enggagement Pada Karyawan PT. Telkom, TBK Divisi Regional IV Semarang. Empati, 3(1), 1-8.

Durrani, F. (2017). Mediating Role of Organizational Justice in Relationship between Islamic Work Ethics and Employee Turnover Intention. Pakistan Journal of Commerce and Social Sciences, 11(3), 1050-1068.

Ghosh, P., Rai, A., \& Sinha, A. (2014). Organizational justice and employee engagement: Exploring the linkage in public sector banks in India. Personnel Review, 43(4), 628-652.

Ghosh, D., Sekiguchi, T., \& Gurunathan, L. (2017). Organizational embeddedness as a mediator between justice and 
in-role performance. Journal of Business Research, 75, 130-137.

Ghozali, I. (2005). Analisis Multivariat dengan Program SPSS Edisi ke3. Semarang: Badan Penerbit Universitas Diponegoro.

Greenberg, J \& Baron, R. (2003). Perilaku Organisasi. Jakarta: Prentice Hall

Greenberg,J.(1993).Thesocialsideoffairness: Interpersonal and informational classes of organizational justice. Dalam R. Cropanzano (Editor), Series in applied psychology. Justice in the workplace: Approaching fairness in human resource management (79103). Lawrence Erlbaum Associates, Inc.

Gupta, V., \& Kumar, S. (2013). Impact of performance appraisal justice on employee engagement: a study of Indian professionals. Employee Relations. 35(1), 61-78.

Haroon, M., Zaman, H. M., \& Rehman, W. (2012). The Relationship between Islamic Work Ethics and Job Satisfaction in Healthcare sector of Pakistan. International Journal of Contemporary Business Studies, 3(5), 6-12.

Karam, E. P., Hu, J., Davison, R. B., Juravich, M., Nahrgang, J. D., Humphrey, S. E., \& Scott DeRue, D. (2019). Illuminating the "face" of justice: A meta-analytic examination of leadership and organizational justice. Journal of Management Studies, 56(1), 134-71.

Khadijah, A. S., Kamaluddin, N., \& Salin, A. S. A. P. (2015). Islamic work ethics (IWE) practice among employees of banking sectors. Middle-East Journal of Scientific Research, 23(5), 924-931.

Khan, K., Abbas, M., Gul, A., \& Raja, U.
(2015). Organizational Justuce and Job Outcomes: Moderating Role of Islamic Work Ethic. Journal Bussiness Ethics, 126(2), 235-246.

Kreitner, R., \& Kinicki, A. (2003). Perilaku Organisasi, Terjemahan: Erly Suandy. Edisi Pertama. Jakarta: Salemba Empat.

Kumar, N., \& Rose, R. C. (2010). Examining the link between Islamic work ethic and innovation capability. Journal of Management Development, 29(1), 79-93.

Lamprakis, A., Alamani, K., Malliari, A., \& Ilias Grivas (2018). The Organisational Justice as a Human Resources Management Practice and its Impact on Employee Engagement: The case of the Prefecture of Attica (Greece). Scientific Annals of Economics and Business, 65(1), 6579.

Lee, Y., Shin, H. Y., Park, J., Kim, W., \& Cho, D. (2017). An integrative literature review on employee engagement in the field of human resource development: Exploring where we are and where we should go. Asia Pacific Education Review, 18(4), 541-557.

Malik, A., Shafiq, M., Iqbal, M., \& Iftikhar, A. (2018). Effect of Islamic Work Ethics on Organizational Citizenship Behavior: Moderating Role of Transformational Leadership And Mediating Role of Organizational Justice. International Conference on Contemporary Issues in Business \& Economics (Iccibe) Conference Proceedings, 550-557.

Margaretha, M., \& Santosa, T. E. (2012). Keadilan Prosedural dan Keadilan Distributif Sebagai Prediktor Employee Engagement. Jurnal Manajemen, 12(1), 103-114. 
Markos, S., \& Sridevi, M. S. (2010). Employee Enggagement: The Key to Improving Performance. International Journal of Business and Management, 5(12), 89-96.

Marri, M. Y., Zaman, H. M., Yousufzai, M. I., \& Nas, Z. (2013). Moderating Role of Islamic Work Ethics between the Relationship of Organizational Commitment and Turnover Intentions: A Study of Public Sector of Pakistan. Mediterranean Journal of Social Sciences, 4(2), 767-775.

Pan, X., Chen, M., Hao, Z., \& Bi, W. (2018). The effects of organizational justice on positive organizational behavior: Evidence from a large-sample survey and a situational experiment. Frontiers in Psychology, 8, 1-16.

Ramalu, S. S., \& Rashid, Z. M. (2017). Islamic Work Ethic, Employee Engagement And Organizational Citizenship Behaviour: A Study Among Civil Servants In Malaysia. Journal of Global Business and Social Entrepreneurship (GBSE), 1(2), 43-55.

Rana, M. S., Iftikhar, U., Abbasi, S. G., \& Abbas, M. (2018). The role of organizational justice to develop organizational citizenship behavior: moderating effect of Islamic work ethics. Amazona Investiga, 7(16), 4660.

Rasheed, A., Khan, S., \& Ramzan, M. (2013). Antecedents and Consequences of Employee Engagement: The Case of Pakistan. Journal of Business Studies Quarterly, 4(4), 183-200.

Rokhman, W. (2010). The Effect of Islamic Work Ethics on Work Outcomes. EJBO Electronic Journal of Business Ethics and Organizational Studiesi, 15(1), 21-27.
Rokhman, W. (2015). Etika Kerja Islam Dan Keadilan Organisasi: Studi Pada BMT di Kabupaten Kudus. Jurnal Penelitian, 9(1), 163-182.

Saks, A.M. (2006), Antecedents and consequences of employee engagement. Journal of Managerial Psychology, 21(7), 600-19.

Saleem, S., Bashir, M., \& Sajid, M. (2016). Relationship between Organizational Justice and Organizational Engagement in Public Sector Banks of Pakistan: Mediating Role of Work Engagement. Abasyn Journal of Social Sciences, Special Issue, 338357.

Salinero, S. F., Abal, Y. N., \& Topa, G. (2019). On the Relationship between Perceived Conflict and Interactional Justice Influenced by Job Satisfaction and Group Identity. Sustainability, 11(24), 1-11.

Salmabadi, M., Fatehi, H., \& Mortezaheidari, M. A. (2015). The role Islamic work ethics in the employee engagement. Journal of Biodiversity and Environmental Sciences (JBES), 6(5), 463-470.

Schaufeli, W. B., Bakker, A. B., \& Salanova, M. (2006). The Measurement of Work Engagement with a Short Questionnaire: A Cross-National Study. EducationalandPsychological Measurement, 66(4), 701-716.

Simpson, P. A., \& Kaminski, M. (2007). Gender, Organizational Justice Perceptions, and Union Organizing. Employ Respons Rights Journal, 19(1), 57-72.

Sugiyono. (2016). Metode Penelitian Kuantitatif, Kualitatif dan $R \& D$, Cetakan ke-24. Bandung: Alfabeta.

Tjahjono, H. K. (2008). Studi Literatur Pengaruh Keadilan Distributif 
dan Keadilan Prosedural Pada Konsekuensinya Dengan Teknik Meta Analisis. Jurnal Psikologi, 35(1), 21-40.

Trevino, L., \& Weaver, G. (2001).

Organizational Justice and ethic program follow-trough: influences on employees' harmful and helpful behavior. Journal of Business Ethics Quarterly, 11(4), 651-657.

Tyler, T. R., \& Blader, S. L. (2000). Cooperation in Groups: Procedural Justice, Social Identity, and Behavioral Engagement. New York: Taylor \& Francis Group.

Yousef, D. A. (2001). Islamic Work Ethic: A moderator between organizational commitment and job satisfaction in a cross-cultural context. Personnel Review, 30(2), 152-169. 
